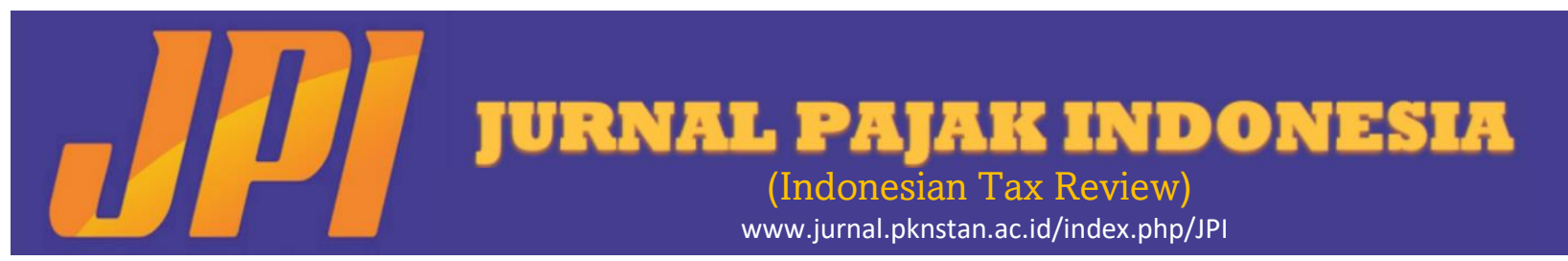

\title{
PUTUSAN MAHKAMAH KONSTITUSI NO. 10/PUU-XVIII/2020 ATAS MEKANISME PENGUSULAN KETUA DAN WAKIL KETUA PENGADILAN PAJAK
}

\author{
Tommy Valentino Sugiono \\ Politeknik Keuangan Negara STAN \\ Supriyadi \\ Politeknik Keuangan Negara STAN \\ Alamat Korespondensi: priesoekarno@pknstan.ac.id
}

INFORMASI ARTIKEL

Diterima Pertama

[31102021]

Dinyatakan Diterima

[12112021]

KATA KUNCI:

Pelaksanaan, Putusan Mahkamah Konstitusi, Pengadilan Pajak

\section{ABSTRAK}

As a special court within the state administrative court, The Tax Court normatively has particular characteristics. One of these characteristics is the authority of the Minister of Finance to propose the Chairman and Deputy Chairperson of the Tax Court by the provisions of Article 8 paragraph (2) of Law Number 14 of 2002 of the Tax Court. Based on the Decision of Case Number 10/PUU-XVIII/2020 on the petition for judicial review of the article, the Constitutional Court decided to grant part of the petition. Thus, the authority of the Minister of Finance is only administrative in nature. This study aims to determine the mechanism and the views of judges and academics regarding the election of the Chairman and Deputy Chairperson of the Tax Court both before and after the Constitutional Court Decision. The research was conducted with qualitative research methods using a library research approach and interviews. Based on this research, it is known that: there are differences in the mechanism for selecting the Chair and Deputy Chair of the Tax Court either before and after the decision of the Constitutional Court; there is a certainty for Tax Court judges after the Constitutional Court Decision; Tax Court judges are independent in deciding tax disputes.

Pengadilan Pajak sebagai pengadilan khusus di lingkungan peradilan tata usaha negara secara normatif memiliki karakteristik khusus. Salah satu karakteristik tersebut yaitu adanya kewenangan Menteri Keuangan untuk mengusulkan Ketua dan Wakil Ketua Pengadilan Pajak sesuai ketentuan pasal 8 ayat (2) Undang-Undang Nomor 14 tahun 2002 tentang Pengadilan Pajak. Berdasarkan Putusan Perkara Nomor 10/PUU-XVIII/2020 terhadap permohonan uji materi atas muatan pasal tersebut, Mahkamah Konstitusi memutuskan mengabulkan sebagian permohonan. Dengan demikian, kewenangan Menteri Keuangan hanya bersifat administratif. Penelitian ini bertujuan untuk mengetahui mekanisme serta pandangan hakim dan akademisi terkait pemilihan Ketua dan Wakil Ketua Pengadilan Pajak baik sebelum maupun setelah Putusan Mahkamah Konstitusi. Penelitian dilakukan dengan metode penelitian kualitatif menggunakan pendekatan penelitian kepustakaan dan wawancara. Berdasarkan penelitian ini, diketahui bahwa terdapat perbedaan mekanisme pemilihan Ketua dan Wakil Ketua Pengadilan Pajak antara sebelum dan setelah putusan Mahkamah Konstitusi, adanya rasa kepastian khususnya bagi hakim Pengadilan Pajak pasca Putusan Mahkamah Konstitusi, dan hakim Pengadilan Pajak pada dasarnya telah independen dalam memutus sengketa pajak. 


\section{PENDAHULUAN}

\subsection{Latar Belakang}

Pengadilan Pajak merupakan lembaga peradilan yang berwenang untuk memeriksa dan memutus sengketa pajak, diluar upaya hukum administratif, yakni keberatan, pengurangan dan pembatalan. Oleh karena itu, Pengadilan Pajak diharapkan hadir sebagai lembaga peradilan yang memberikan keadilan dan kepastian hukum bagi wajib pajak.

Sebagai salah satu pelaksana fungsi yudikatif dalam lingkup peradilan khusus di lingkungan peradilan tata usaha negara, Pengadilan Pajak secara normatif memiliki karakteristik khusus. Salah satu karakteristik tersebut yaitu ketentuan mengenai pihak yang terlibat dalam pembinaan Pengadilan Pajak. Pasal 5 ayat (1) dan (2) Undang-Undang Nomor 14 tahun 2002 tentang Pengadilan Pajak (selanjutnya disebut UU Pengadilan Pajak) menegaskan bahwa pembinaan teknis peradilan dilakukan oleh Mahkamah Agung, sedangkan pembinaan organisasi, administrasi, dan keuangan dilakukan oleh Kementerian Keuangan. Lebih lanjut, pasal 8 ayat (2) UU Pengadilan Pajak juga memberikan kewenangan kepada Menteri Keuangan untuk mengusulkan Ketua dan Wakil Ketua Pengadilan Pajak. Sementara itu, Undang-Undang Dasar Negara Republik Indonesia 1945 (UUD 1945) dalam pasal 24 ayat (1) dan (2) telah menjelaskan bahwa pelaku kekuasaan kehakiman dalam menjalankan fungsinya lepas dari pengaruh pelaku kekuasaan yang lain dan mereka berkuasa untuk mengatur urusan rumah tangganya sendiri (Subiyanto, 2012).

Masih adanya pengaruh Kementerian Keuangan dan Menteri Keuangan dalam pembinaan Pengadilan Pajak acapkali menimbulkan pertanyaan terkait independensi Pengadilan Pajak dalam menjalankan wewenangnya. Seperti pendapat Rumadan (2012), adanya kewenangan pemerintah (eksekutif) melalui Kementerian Keuangan dianggap dapat memengaruhi independensi Pengadilan Pajak terutama para hakim dalam mengambil suatu keputusan. Meskipun demikian, UU Pengadilan Pajak itu sendiri sebenarnya sudah memberikan jaminan bahwa pembinaan organisasi oleh Kementerian Keuangan tidak boleh mengurangi kebebasan/independensi hakim dalam memutus suatu sengketa pajak. Selain itu, UndangUndang No 48 tahun 2009 tentang Kekuasaan Kehakiman pada pasal 21 ayat (2) juga telah menjelaskan bahwa ketentuan organisasi, administrasi, dan finansial badan peradilan di bawah Mahkamah Agung diatur dengan undang-undang sesuai kekhususan lingkungan peradilan masingmasing.

Terdapat indikasi atau kekhawatiran akan pengaruh kemenkeu terhadap independensi Pengadilan Pajak yang dapat juga terjadi melalui sistem atau mekanisme pemilihan Ketua Pengadilan Pajak, dimana menurut Pasal 8 ayat (2) UU Pengadilan Pajak, kewenangan pengusulannya ada pada Menteri Keuangan.
Pimpinan Pengadilan Pajak, dalam hal ini ketua, memiliki beberapa peran atau wewenang terhadap tata organisasi pengadilan pajak itu sendiri. Pertama, pasal 47 UU Pengadilan Pajak memberikan wewenang kepada Ketua Pengadilan Pajak untuk menunjuk Majelis atau Hakim Tunggal yang bertugas untuk memeriksa dan memutus Sengketa Pajak. Kedua, pasal 11 UU Pengadilan Pajak menyebutkan Ketua melakukan pembinaan dan pengawasan pelaksanaan tugas dan perilaku Wakil Ketua, Hakim, dan Sekretaris/Panitera. Ketiga, pasal 9 ayat (2) juga memberikan wewenang kepada Ketua untuk menunjuk hakim ad hoc sebagai hakim anggota dalam memeriksa dan memutus perkara sengketa pajak tertentu yang memerlukan keahlian khusus. Berdasarkan uraian tersebut, maka kewenangan Menteri Keuangan untuk mengusulkan Ketua dan Wakil Ketua Pengadilan Pajak patut menjadi perhatian mengingat ketualah yang akan memiliki peran terhadap organisasi itu sendiri.

Pada bulan Februari tahun 2020, terdapat permohonan uji materi pasal 5 ayat (2) dan pasal 8 ayat (2) UU Pengadilan Pajak terkait kewenangan Menteri Keuangan untuk mengusulkan Ketua dan Wakil Ketua Pengadilan Pajak. Permohonan uji materi tersebut telah diputus oleh Mahkamah Konstitusi pada bulan September tahun 2020 dengan amar putusan mengabulkan sebagian permohonan. Putusan tersebut diuraikan dalam Putusan Perkara No. 10/PUU-XVIII/2020. Dalam amar putusannya, pada intinya mahkamah menyatakan bahwa pasal 8 ayat (2) UU Pengadilan Pajak:

. . . bertentangan dengan Undang-Undang Dasar Negara Republik Indonesia Tahun 1945 dan tidak memiliki kekuatan hukum mengikat sepanjang tidak dimaknai, "Ketua dan Wakil Ketua diangkat oleh Presiden yang dipilih dari dan oleh para Hakim yang selanjutnya diusulkan melalui Menteri dengan persetujuan Ketua Mahkamah Agung untuk satu kali masa jabatan selama 5 (lima) tahun)."

Dengan demikian, peran Menteri Keuangan untuk mengusulkan Ketua dan Wakil Ketua Pengadilan Pajak hanya bersifat administratif.

Dari uraian di atas, ketentuan pengusulan Ketua dan Wakil Ketua Pengadilan Pajak menarik untuk diteliti lebih lanjut. Pertama, ketua atau pimpinan Pengadilan Pajak memiliki peranan penting terhadap organisasi Pengadilan Pajak. Kedua, merujuk Laporan Tahunan Mahkamah Agung tahun 2018, Pengadilan Pajak merupakan pengadilan dengan jumlah beban perkara terbanyak daripada pengadilan tingkat banding di empat lingkungan peradilan lainnya (peradilan umum, agama, militer, dan TUN).

Lebih lanjut, berdasarkan statistik dalam website Sekretariat Pengadilan Pajak, jumlah berkas sengketa pajak dari tahun 2017 s.d. 2019 terus mengalami peningkatan dari 9.579 berkas pada tahun 2017 menjadi 15.048 berkas pada tahun 2019. Sementara itu, saat ini terdapat 63 (enam puluh tiga) hakim di Pengadilan Pajak termasuk 4 (empat) orang hakim di dalamnya menjabat sebagai Ketua, Wakil Ketua I, Wakil Ketua II, dan Wakil Ketua III. Ketiga, Kementerian Keuangan, dalam hal ini Direktorat 
Jenderal Pajak (DJP) dan Direktorat Jenderal Bea dan Cukai (DJBC), pada dasarnya merupakan salah satu pihak yang bersengketa di Pengadilan Pajak.

Tabel 1.1 Persentase Kemenangan DJP dalam Sengketa Banding dan Gugatan Selama 5 (lima) Tahun Terakhir

\begin{tabular}{|l|c|c|c|c|c|}
\hline \multicolumn{1}{|c|}{ Tahun } & $\mathbf{2 0 1 6}$ & $\mathbf{2 0 1 7}$ & $\mathbf{2 0 1 8}$ & $\mathbf{2 0 1 9}$ & $\mathbf{2 0 2 0}$ \\
\hline Menang (\%) & 44,87 & 50,98 & 43,54 & 40,54 & 43,1 \\
\hline Rata-rata & \multicolumn{5}{|c|}{$44,61 \%$} \\
\hline
\end{tabular}

Sumber: diolah dari Laporan Kinerja DJP Tahun 2016 s.d. 2020

Tabel 1.2 Persentase Kemenangan DJP dalam Sengketa Banding dan Gugatan Selama 5 (lima) Tahun Terakhir

\begin{tabular}{|l|c|c|c|c|c|}
\hline Menang/Kalah & $\mathbf{2 0 1 6}$ & $\mathbf{2 0 1 7}$ & $\mathbf{2 0 1 8}$ & $\mathbf{2 0 1 9}$ & $\mathbf{2 0 2 0}$ \\
\hline Menang & 2669 & 2034 & 1883 & 1693 & 285 \\
\hline Kalah & 2970 & 3042 & 2807 & 3404 & 464 \\
\hline Jumlah & 5639 & 5076 & 4690 & 5097 & 749 \\
\hline \% Menang & 47,33 & 40,07 & 40,15 & 33,21 & 38,05 \\
\hline \% Rata-rata & \multicolumn{5}{|c|}{$39,76 \%$} \\
\hline
\end{tabular}

Sumber: diolah dari data dalam Putusan MK No. 10/PUU-XVIII/2020

Tabel 1.3 Persentase Kemenangan DJBC dalam Sengketa Banding dan Gugatan Selama 5 (lima) Tahun Terakhir

\begin{tabular}{|l|c|c|c|c|c|}
\hline Menang/Kalah & $\mathbf{2 0 1 6}$ & $\mathbf{2 0 1 7}$ & $\mathbf{2 0 1 8}$ & $\mathbf{2 0 1 9}$ & $\mathbf{2 0 2 0}$ \\
\hline Menang & 1557 & 1199 & 1148 & 1300 & 94 \\
\hline Kalah & 2259 & 1961 & 2449 & 1602 & 131 \\
\hline Jumlah & 3816 & 3160 & 3597 & 2902 & 225 \\
\hline \% Menang & 40,80 & 37,94 & 31,92 & 44,80 & 41,78 \\
\hline \% Rata-rata & \multicolumn{5}{|c|}{$39,45 \%$} \\
\hline
\end{tabular}

Sumber: diolah dari data dalam Putusan MK No. 10/PUU-XVIII/2020 1

Adanya putusan Mahkamah Konstitusi yang memisahkan kewenangan Menteri Keuangan untuk terlibat langsung dalam proses pengusulan Ketua dan Wakil Ketua Pengadilan Pajak tentu memiliki arti penting, tidak hanya bagi Pengadilan Pajak, namun juga bagi wajib pajak. Wajib pajak sebagai salah satu pihak yang bersengketa memiliki hak untuk memperoleh kepastian hukum dan keadilan. Pun demikian dengan negara sebagai pemungut pajak. Keberadaan putusan Mahkamah Konstitusi tersebut dapat dimaknai secara positif. Putusan tersebut dapat dikatakan telah memberikan titik terang dan menguatkan independensi organisasi Pengadilan Pajak secara institusional. Dengan demikian, jaminan kepastian hukum dan rasa keadilan bagi wajib pajak ketika menghadapi sengketa pajak di Pengadilan Pajak secara tidak langsung juga akan meningkat.

Berdasarkan uraian di atas, maka penulis tertarik untuk memahami bagaimana proses pengusulan Ketua dan Wakil Ketua Pengadilan Pajak, baik sebelum maupun setelah adanya putusan uji materi dari Mahkamah Konstitusi. Dengan demikian, penulis menyusun penelitian ini dengan judul "PELAKSANAAN
PUTUSAN MAHKAMAH KONSTITUSI NO. 10/PUUXVIII/2020 ATAS MEKANISME PENGUSULAN KETUA DAN WAKIL KETUA PENGADILAN PAJAK".

\subsection{Rumusan Masalah}

Berdasarkan uraian latar belakang di atas, rumusan masalah dalam penelitian ini adalah sebagai berikut:

a. Bagaimana pandangan hakim Pengadilan Pajak terkait mekanisme pemilihan Ketua dan Wakil Ketua Pengadilan Pajak sebelum dan setelah Putusan Mahkamah Konstitusi No. 10/PUUXVIII/2020?

b. Bagaimana pandangan akademisi terkait mekanisme pemilihan Ketua dan Wakil Ketua Pengadilan Pajak sebelum dan setelah Putusan Mahkamah Konstitusi No. 10/PUU-XVIII/2020?

\subsection{Tujuan Penelitian}

Berdasarkan uraian latar belakang dan rumusan masalah di atas, maka tujuan penelitian ini adalah sebagai berikut:

a. Mengetahui pandangan hakim Pengadilan Pajak terkait mekanisme pemilihan Ketua dan Wakil Ketua Pengadilan Pajak sebelum dan setelah Putusan Mahkamah Konstitusi No. 10/PUUXVIII/2020.

b. Mengetahui pandangan akademisi terkait mekanisme pemilihan Ketua dan Wakil Ketua Pengadilan Pajak sebelum dan setelah Putusan Mahkamah Konstitusi No. 10/PUU-XVIII/2020.

\section{KERANGKA TEORI}

\subsection{Asas Pelaksanaan Pemungutan Pajak}

Adanya asas pelaksanaan pemungutan pajak bertujuan agar pemungutan pajak dapat dilaksanakan dengan baik, adil, lancar, tidak mengganggu kepentingan masyarakat, sekaligus membawa hasil yang baik bagi kas negara (Pudyatmoko, 2009). Pelaksanaan pemungutan pajak yang berpegang pada asas akan meminimalkan terjadinya sengketa pajak. Walau demikian, sengketa pajak tetap dapat terjadi akibat perbedaan persepsi antara wajib pajak dengan fiskus dalam menafsirkan suatu ketentuan. Semakin meningkatnya jumlah sengketa pajak ke Pengadilan Pajak setidaknya dapat menjadi pemantik kajian bagi berbagai pihak untuk meneliti penyebab naiknya jumlah sengketa pajak. Menurut Pudyatmoko (2009), terdapat 3 (tiga) asas pelaksanaan pemungutan pajak, yaitu sebagai berikut.

a. Asas Yuridis

Santoso Brotodihardjo (1991, dikutip dalam Pudyatmoko, 2009) menyatakan bahwa dengan asas yuridis, hukum pajak harus dapat memberikan jaminan hukum demi mencapai keadilan, baik bagi negara maupun warga negaranya. Oleh karena itu, semua hal yang berkaitan dengan pelaksanaan

\footnotetext{
${ }^{1}$ Berdasarkan Putusan No. 10/PUU-XVIII/2020, hlm.60, data jumlah putusan tahun 2020 yang disajikan, baik DJP dan DJBC, adalah jumlah per Februari 2020.
} 
pemungutan pajak harus berlandaskan pada undangundang untuk menciptakan jaminan dan perlindungan hukum. Perlindungan hukum ini diberikan baik kepada fiskus maupun wajib pajak.

b. Asas Ekonomis

Pada asas ekonomis, Pudyatmoko (2009) menekankan pada fungsi pajak yang memiliki fungsi mengatur (regulerend). Pemungutan pajak harus memperhatikan aspek kesanggupan dan kemanfaatan. Jika pemungutan pajak memberatkan masyarakat dan pemanfaatannya tidak tepat sasaran, maka akan menimbulkan resistensi dari masyarakat yang kemudian secara ekonomis akan menyulitkan pelaksanaan pemungutan pajak.

c. Asas Finansial

Jika asas ekonomis menekankan pada fungsi regulerend, maka fungsi pajak yang penting berdasar asas finansial adalah fungsi budgetair, yakni mengumpulkan pajak semaksimal mungkin ke kas negara. Oleh karena itu, supaya hasil pemungutan pajak optimal maka biaya pemungutannya juga harus seminimal mungkin dengan memperhitungkan efisiensi pengeluaran dalam pemungutan pajak.

\subsection{Konsep Negara Hukum dan Pemisahan Kekuasaan}

Untuk memaknai kembali marwah dari suatu lembaga peradilan, khususnya Pengadilan Pajak, perlu menilik kembali pada filosofi hadirnya kekuasaan kehakiman berdasarkan konsep negara hukum dan pemisahan kekuasaan.

a. Konsep Negara Hukum

Pemahaman akan konsep negara hukum di Indonesia pertama-tama perlu merujuk pada konstitusi sebagai kaidah fundamental negara. Di dalam Penjelasan atas Undang-Undang Dasar Negara Republik Indonesia Tahun 1945 (UUD 1945) telah disebutkan dengan jelas bahwa, Indonesia adalah negara yang berdasar atas hukum (rechtsstaat) dan tidak berdasar pada kekuasaan belaka (machtsstaat). Konsep negara Indonesia sebagai negara yang berdasar atas hukum diwujudkan dalam Pasal 1 ayat (3) UUD 1945 pasca amandemen yang menegaskan bahwa "Negara Indonesia adalah negara hukum."

Dalam paham Negara Hukum, penyelenggaraan negara haruslah berlandaskan pada hukum, bukan berdasarkan kekuasaan. Asshiddiqie (2006a) mengungkapkan bahwa, "hukum tidak boleh dibuat, ditetapkan, ditafsirkan, dan ditegakan dengan tangan besi atau berdasar kekuasaan belaka (machtsstaat)." Dengan demikian, diperlukan prinsip demokrasi dan kedaulatan rakyat agar supremasi hukum dapat terwujud. Pemikiran awal lahirnya konsep negara hukum dimaksudkan untuk membatasi kekuasaan negara. Pembatasan kekuasaan bertujuan agar dalam proses penyelenggaraan negara, penguasa atau pemerintah tidak bertindak sewenang-wenang.

Konsep negara hukum memiliki beragam istilah. Di Indonesia sendiri, istilah negara hukum sering disebut dengan rechtstaat atau the rule of law. Namun kedua istilah tersebut sebenarnya memiliki perbedaan berdasarkan latar belakang aliran negara hukum yang dianut (Siallagan, 2016). Negara-negara dengan aliran Eropa Kontinental, seperti Belanda, yang menganut sistem hukum civil law memiliki konsepsi negara hukum dengan istilah rechtsstaat. Sedangkan negaranegara aliran Anglo-Saxon, misalnya Inggris, yang menganut sistem hukum common law memaknai konsep negara hukum dengan istilah the rule of the law.

Julius Stahl, (dikutip dalam Asshiddiqie, 2006a) menyebutkan bahwa konsep negara hukum yang disebut dengan istilah 'rechtsstaat' terdiri atas empat elemen penting, yaitu:

- adanya perlindungan terhadap hak asasi manusia;

- adanya pembagian kekuasaan;

- pemerintahan yang berdasarkan pada undangundang; dan

- peradilan tata usaha negara

Sementara itu, A.V. Dicey (dikutip dalam Asshiddiqie, 2006a) menguraikan tiga ciri-ciri konsep negara hukum yang lazim disebut dengan istilah "the Rule of Law", yaitu:

- supremacy of law (supremasi hukum);

- equality before the law (persamaan kedudukan di dalam hukum); dan

- due process of law (asas legalitas).

Meskipun terdapat perbedaan, dalam perkembangannya dewasa ini, perbedaan tersebut tidak lagi dipermasalahkan. Hal ini karena kedua konsep tersebut pada dasarnya sama-sama mengarah pada perlindungan terhadap hak-hak asasi manusia. (Ni'matul Hud, 2013 dikutip dalam Simamora, 2014).

Pasca amandemen UUD 1945, Indonesia tidak merujuk secara langsung terhadap konsep negara hukum rechtsstaat ataupun rule of law. Namun, Indonesia mengolaborasi kedua prinsip negara hukum tersebut (Siallagan, 2016). Penerapan prinsip negara hukum di Indonesia dapat dijumpai dalam konstitusi yang ditandai dengan adanya pengaturan mengenai perlindungan terhadap hak asasi manusia, pemisahan atau pembagian kekuasaan, pelaksanaan kedaulatan rakyat, penyelenggaraan pemerintahan yang didasarkan pada peraturan perundang-undangan yang berlaku, serta adanya peradilan administrasi negara.

b. Teori Pemisahan Kekuasaan

Konsep awal mengenai pemisahan kekuasaan atau pembagian kekuasaan pertama kali dikemukakan oleh John Locke dalam Second Treaties of Civil Government (1690, dikutip dalam Asshiddiqie, 2006b), yang menyatakan bahwa kekuasaan untuk menetapkan peraturan tidak boleh dipegang oleh mereka yang melaksanakannya juga. Pemikiran John Locke tersebut kemudian diteruskan oleh Baron de Montesquieu dengan konsep trias politica yang membagi kekuasaan negara menjadi tiga cabang kekuasaan, yakni legislatif, eksekutif dan yudikatif. Konsep trias politica Montesquieu inilah yang menjadi rujukan teori separation of power.

Istilah "pemisahan kekuasaan" di Indonesia merupakan terjemahan dari separation of power berdasarkan tiga cabang kekuasaan yang harus dibedakan dan tidak boleh saling mencampuri urusan satu sama lain (Asshiddiqie, 2006b). Hal ini berarti 
urusan legislatif (pembentukan undang-undang) harus dijalankan oleh lembaga legislatif, kekuasaan eksekutif (pelaksana undang-undang) hanya dilaksanakan oleh lembaga eksekutif, dan kekuasaan yudikatif (kekuasaan kehakiman atau peradilan) hanya dapat dilakukan oleh lembaga yudikatif. Adanya pemisahan kekuasaan pada dasarnya bertujuan untuk mencegah pemerintahan yang semena-mena apabila semua cabang kekuasaan dilaksanakan oleh satu orang atau lembaga pemerintahan. Namun, konsep pemisahan kekuasaan Montesquieu dianggap tidak dapat dilaksanakan secara murni. Seperti diungkapkan Rahmatullah (2013), konsep separation of power dalam trias politica Montesquieu sulit terlaksana karena cabang kekuasaan atau lembaga negara yang satu dengan yang lain tidak mungkin tidak saling bersentuhan. Hal inilah yang menyebabkan teori pembagian kekuasaan (distribution of power) lebih berkembang dan digunakan di berbagai Negara, hingga akhirnya memunculkan konsep checks and balances.

Baik istilah separation of power maupun distribution of power mempunyai arti yang sama tergantung dari konteks yang dianut. Hanya saja, Asshiddiqie (2006b) menggarisbawahi bahwa makna distribution/division of power di Indonesia erat kaitannya dengan pembagian kekuasaan secara vertikal sebagaimana dalam Pasal 18 ayat (1) UUD 1945. Pembagian kekuasaan secara vertikal menegaskan adanya hubungan hierarkis vertikal antara pemerintah pusat, pemerintah daerah provinsi, dan pemerintah kabupaten/kota. Oleh karena itu, Asshiddiqie (2006b) lebih menyarankan istilah pembagian kekuasaan secara horizontal, yakni antar cabang kekuasaan, yang dianut oleh Indonesia pasca amandemen UUD 1945 adalah sistem pemisahan kekuasaan berdasarkan prinsip checks and balances.

Penjelasan singkat mengenai pembagian ketiga cabang kekuasaan di Indonesia diuraikan sebagai berikut.

\section{- Cabang Kekuasaan Legislatif}

Kekuasaan legislatif adalah cabang kekuasaan yang mencerminkan kedaulatan rakyat. Adanya lembaga legislatif atau lembaga perwakilan rakyat merupakan perwujudan dari kedaulatan rakyat melalui representasi wakil-wakilnya yang dipilih melalui pemilihan umum.

\section{- Cabang Kekuasaan Eksekutif}

Kekuasaan eksekutif adalah cabang kekuasaan yang berwenang untuk menyelenggarakan pemerintahan berdasarkan undang-undang dasar. Cabang kekuasaan eksekutif tidak hanya berbicara mengenai kekuasaan pemerintah pusat. Karena penyelenggaraan pemerintahan juga dilaksanakan pada lingkup daerah, maka kekuasaan eksekutif juga mencakup kekuasaan pemerintahan daerah di dalamnya.

\section{- Cabang Kekuasaan Yudikatif}

Cabang kekuasaan yudikatif erat kaitannya dengan penyelenggaraan kekuasaan kehakiman. Di Indonesia, kekuasaan kehakiman dipegang oleh
Mahkamah Konstitusi dan Mahkamah Agung beserta lembaga peradilan di bawahnya.

Mengenai hubungan antar cabang kekuasaan di atas, Asshiddiqie (2006a) memaparkan bahwa ketiga cabang kekuasaan tersebut dibatasi namun samasama sederajat dan saling mengontrol satu sama lain sesuai prinsip checks and balances. Dengan prinsip tersebut, maka kekuasaan negara dapat diatur dan dikontrol untuk mencegah penyalahgunaan kekuasaan oleh penyelenggara negara yang sedang menduduki jabatan tertentu dalam pemerintahan.

\subsection{Teori Independensi}

Muchsin (2004, dikutip dalam Jan, 2012) mengungkapkan bahwa independensi hakim yang berasal dari kata independence of the judiciary memiliki padanan istilah dengan kekuasaan kehakiman yang merdeka. Sejalan dengan yang diungkapkan Kornhauser (2002), istilah 'judicial independence' secara umum digunakan untuk melengkapi istilah atau konsep terkait seperti 'separation of power' dan 'the rule of law', meskipun keduanya memiliki perbedaan fungsi. Konsep separation of power berbicara tentang kekuasaan pemerintah, yakni mengatur hubungan antar lembaga negara dan antara lembaga negara dengan masyarakatnya. Sedangkan independensi umumnya berkaitan dengan penyelesaian sengketa hukum antar individu dan sengketa hukum antara pemerintah dengan warga negaranya. Karenanya, definisi independensi secara yuridis-sederhana diartikan sebagai bebas dari pengaruh siapa pun.

Mahkamah Agung dalam Cetak Biru Pembaruan Peradilan 2010 - 2035 menjelaskan hal berikut:

Syarat utama terselenggaranya suatu proses peradilan yang obyektif adalah adanya kemandirian lembaga yang menyelenggarakan peradilan, yaitu kemandirian badan peradilan sebagai sebuah lembaga (kemandirian institusional), serta kemandirian hakim dalam menjalankan fungsinya (kemandirian individual/fungsional). Kemandirian menjadi kata kunci dalam usaha melaksanakan tugas pokok dan fungsi badan peradilan secara efektif.

Berdasarkan Cetak Biru tersebut, konsep mengenai kemandirian institusional berkaitan dengan penyatuatapan lembaga peradilan di bawah Mahkamah Agung sebagaimana diatur dalam Pasal 21 UU Kekuasaan Kehakiman. Oleh karena itu, badanbadan peradilan secara organisasi, administratif, dan finansial berada di bawah kekuasaan Mahkamah Agung. Selaras dengan pendapat Jimly Asshiddiqie di dalam Cetak Biru tersebut, adanya independensi institusional bertujuan agar pelaksanaan tugas kekuasaan kehakiman tidak terganggu. Pembinaan kekuasaan kehakiman di bawah satu atap dianggap penting untuk mewujudkan kekuasaan kehakiman yang independen (bebas) dan imparsial (tidak memihak) (Asshiddiqie, 2006a).

Selain konsep independensi institusional, independensi/kemandirian individual juga tidak dapat dipisahkan dari kemandirian badan peradilan. Kemandirian individual berkaitan erat dengan aspek kemandirian hakim untuk memutus sengketa yang terkait dengan tujuan penyelenggaraan pengadilan. Konsepsi kemandirian hakim dipertegas di dalam 
Keputusan Bersama Ketua Mahkamah Agung Republik Indonesia dan Ketua Komisi Yudisial Nomor 047/KMA/SKB/IV/2009 dan 02/SKB/P.KY/IV/2009 tentang Kode Etik dan Pedoman Perilaku Hakim. Di dalam Pengaturan angka 4, penerapan perilaku hakim yang harus bersikap mandiri adalah sebagai berikut.

- Hakim harus menjalankan fungsi peradilan secara mandiri dan bebas dari pengaruh, tekanan, ancaman atau bujukan, baik yang bersifat langsung maupun tidak langsung dari pihak manapun.

- Hakim wajib bebas dari hubungan yang tidak patut dengan lembaga eksekutif maupun legislatif serta kelompok lain yang berpotensi mengancam kemandirian (independensi) Hakim dan Badan Peradilan.

- Hakim wajib berperilaku mandiri guna memperkuat kepercayaan masyarakat terhadap Badan Peradilan.

Penerapan kemandirian individual hakim bahkan telah disebutkan dalam Pasal 5 ayat (3) dan Pasal 11 ayat (3) UU Pengadilan Pajak. Melalui ketentuan tersebut ditegaskan bahwa pembinaan dan pengawasan tidak boleh mengurangi kebebasan hakim dalam memeriksa dan memutus sengketa pajak.

Sulistiyono (2018) mengungkapkan bahwa konsep mengenai independensi peradilan memiliki beragam bentuk tergantung dari sudut pandang apa independensi itu ditinjau. Salah satu bentuk independensi yang paling mendasar adalah independensi putusan, yaitu mengacu pada kemampuan hakim untuk memutuskan kasus secara independen tanpa campur tangan dari pihak lain. Sebagai prasyarat agar indepensi putusan terwujud, hakim harus memperoleh independensi personal. Independensi personal mengharuskan adanya jaminan rasa aman terhadap hakim terutama yang berkaitan dengan masa jabatannya dengan adanya ketentuan:

- mekanisme pengangkatan dan promosi yang terdepolitisasi atau bebas dari kepentingan pihak lain;

- perolehan penghasilan hakim yang memadai;

- hakim tidak boleh diberhentikan atau dikurangi penghasilannya selama tugas dan fungsinya dilakukan dengan memadai;

- sistem mutasi dan promosi yang adil serta sesuai dengan peraturan yang berlaku, dan

- hakim harus menerima dan memeriksa kasus dengan tidak memihak.

Apabila hakim telah memperoleh jaminan akan independensi personalnya, maka mereka akan mampu memutus suatu sengketa dengan terbebas dari pengaruh apa pun. Dengan demikian, independensi personal yang diperoleh hakim pada akhirnya akan memberikan jaminan kepastian hukum dan independensi suatu lembaga peradilan.

\section{METODE PENELITIAN}

Dalam menyusun penelitian ini, penulis melakukan prosedur penelitian sebagai berikut:
Penelitian dilakukan dengan menggunakan metode kualitatif. Penelitian didesain dengan cara menganalisis ketentuan pelaksanaan pemilihan Ketua dan Wakil Ketua Pengadilan Pajak, dan pandangan yang diperoleh dari wawancara dengan narasumber. Selain itu, penulis juga menguraikan peraturan perundangundangan serta teori yang terkait.

\subsection{Metode Pengumpulan Data}

Data yang dikumpulkan dalam penelitian ini diperoleh melalui penelitian kepustakaan dan penelitian lapangan. Metode penelitian kepustakaan dilakukan dengan mengkaji data sekunder berupa dokumen dan literatur yang terkait dengan topik penelitian. Dengan metode ini, penulis mengumpulkan data dari berbagai sumber seperti Putusan Mahkamah Konstitusi, peraturan perundang-undangan, jurnal dan artikel dari internet, website resmi Pengadilan Pajak dan Mahkamah Konstitusi, serta buku-buku lain yang relevan.

Sementara itu, penelitian lapangan dilakukan dengan cara terlibat secara langsung di lapangan. Metode ini berguna untuk memberikan gambaran dan pemahaman bagi peneliti terhadap objek penelitian, terutama terkait proses pemilihan Ketua dan Wakil Ketua Pengadilan Pajak. Mengingat situasi pandemi, penulis memanfaatkan teknologi untuk memperoleh data primer. Penulis memperoleh data melalui media surat elektronik (surel/email) dari Sekretariat Pengadilan Pajak dan wawancara. Penulis melakukan wawancara dengan hakim Pengadilan Pajak, dosen mata kuliah Penagihan dan Sengketa Pajak PKN STAN, serta dosen PKN STAN yang juga menjadi Penelaah Keberatan di Direktorat Jenderal Pajak sebagai narasumber. Wawancara dilakukan dengan sarana Zoom Cloud Meeting dan aplikasi Whatsapp call. Selanjutnya, pada penelitian ini para narasumber akan disebut dengan N1, N2, N3, N4, dan N5.

\section{HASIL PENELITIAN}

\subsection{Ketentuan Pengusulan Ketua dan Wakil Ketua Pengadilan Pajak Sebelum Putusan Mahkamah Konstitusi No. 10/PUU-XVIII/2020}

Ketentuan pengusulan Ketua dan Wakil Ketua Pengadilan Pajak pada dasarnya merujuk pada Pasal 8 ayat (2) UU Pengadilan Pajak yang menjelaskan bahwa, "Ketua dan Wakil Ketua diangkat oleh Presiden dari para Hakim yang diusulkan Menteri setelah mendapat persetujuan Ketua Mahkamah Agung." Berdasarkan hasil konfirmasi dari Sekretariat Pengadilan Pajak dan wawancara dengan hakim, mekanisme pemilihan Ketua dan Wakil Ketua Pengadilan Pajak yang pernah berjalan tidak diatur dalam aturan turunan atau petunjuk teknis tersendiri. Oleh karena itu, tidak diperoleh data petunjuk teknis atau ketentuan yang lebih rinci mengenai prosedur pemilihan Ketua dan Wakil Ketua Pengadilan Pajak sebelum adanya Putusan Mahkamah Konstitusi.

Namun berdasarkan fakta pada Putusan Mahkamah Konstitusi No. 10/PUU-XVIII/2020, diketahui bahwa usulan calon Ketua dan Wakil Ketua 
Pengadilan Pajak disampaikan kepada Menteri Keuangan dengan cara sebagai berikut.

- Calon Ketua Pengadilan Pajak diusulkan oleh Ketua Pengadilan Pajak (PP) eksisting;

- Calon Wakil Ketua Pengadilan Pajak diusulkan oleh Ketua bersama dengan Wakil Ketua PP eksisting.

Pengusulan oleh Ketua dan Wakil Ketua eksisting didasarkan pada pertimbangan bahwa Ketua dan Wakil Ketua eksisting memiliki pengetahuan dan pengenalan yang cukup terhadap seluruh Hakim Pengadilan Pajak.

Setelah diusulkan, terhadap calon Ketua dan Wakil Ketua Pengadilan Pajak akan dilakukan penelitian level of integrity and leadership oleh Kementerian Keuangan. Penelitian tersebut bertujuan untuk memastikan bahwa calon pemimpin Pengadilan Pajak memiliki kemampuan untuk memimpin Pengadilan Pajak serta dapat membangun tata kelola dan modernisasi fungsi judiciary Pengadilan Pajak. Dengan demikian jangkauan keadilan bagi wajib pajak dan negara sebagai pihak-pihak yang bersengketa dapat meningkat.

Kementerian Keuangan mampu melakukan penelitian level of integrity and leadership karena adanya data profiling Hakim Pengadilan Pajak yang dimiliki oleh Kementerian Keuangan. Proses tersebut tentu cukup wajar karena sebagian besar hakim Pengadilan Pajak sebelumnya berasal dari Kementerian Keuangan, khususnya Direktorat Jenderal Pajak dan Direktorat Jenderal Bea dan Cukai. Selanjutnya, Calon Ketua dan Wakil Ketua Pengadilan Pajak akan diusulkan Menteri Keuangan kepada Presiden apabila telah disetujui oleh Mahkamah Agung. Adanya persetujuan bersama antara Menteri Keuangan dan Mahkamah Agung ini merupakan perwujudan check and balances antara eksekutif dan yudikatif.

Berdasarkan mekanisme yang ditetapkan tersebut, terdapat beberapa hal yang patut menjadi perhatian. Pertama, tidak adanya ketentuan atau aturan turunan mengenai proses pengusulan Ketua dan Wakil Ketua Pengadilan Pajak sesuai muatan pasal 8 ayat (2) UU Pengadilan Pajak. Jika melihat di dalam penjelasan pasal UU Pengadilan Pajak, hanya disebutkan "cukup jelas". Demikian juga berdasarkan hasil konfirmasi yang diperoleh dari Sekretariat Pengadilan Pajak, disebutkan tidak ada semacam aturan turunan atau petunjuk teknis yang terkait. Tidak adanya ketentuan turunan akan menyebabkan ketidakpastian mengenai proses pengusulan yang berlaku. Hal tersebut terungkap di dalam fakta persidangan bahwa mekanisme pengusulan pada satu periode bisa berbeda dan berubah-ubah pada periode lainnya. Padahal, dengan adanya frasa "diangkat oleh Presiden dari para hakim yang diusulkan oleh Menteri Keuangan", dapat diartikan bahwa Menteri Keuangan berwenang untuk menetapkan mekanisme yang diperlukan. Oleh karena itu diperlukan penegasan mengenai pedoman atau cara yang dilakukan oleh Menteri Keuangan dalam memilih calon pemimpin Pengadilan Pajak. Selain itu, di dalam undang-undang juga tidak dijumpai ketentuan mengenai syarat-syarat atau kriteria tertentu untuk menentukan apakah seorang hakim dapat dicalonkan menjadi ketua dan wakil ketua. Tanpa adanya standar yang jelas akan sulit bagi sesama hakim untuk mengetahui dan menilai secara objektif calon pimpinannya, meskipun terdapat proses profiling dan penelitian level of integrity dan leadership dari Kementerian Keuangan. Lebih lanjut, para hakim Pengadilan Pajak juga akan mengalami ketidakpastian karier.

Kedua, mekanisme pengusulan yang dilakukan oleh ketua dan wakil existing dapat menimbulkan persepsi subjektivitas di antara para hakim Pengadilan Pajak. Selain itu, tidak terbukanya kriteria yang digunakan oleh pimpinan berpotensi menimbulkan nepotisme dalam menentukan calon pimpinan selanjutnya. Ini tentu sejalan dengan pendapat Para Pemohon uji materi yang mengungkapkan bahwa, "Ketidakjelasan persyaratan dan inkonsistensi mekanisme pengusulan Ketua dan Wakil Ketua ... . berpotensi terjadinya nepotisme dan like and dislike dalam proses pengusulannya . ..." (Putusan MK No. 10/PUU-XVIII/2020, p. 12).

Sebagai gambaran, narasumber N4 dan N5 memaparkan bahwa pada tahun 2020 terjadi pergantian 2 (dua) orang Wakil Ketua Pengadilan Pajak yang telah habis masa jabatannya karena pensiun. Pada prosesnya, saat itu terdapat 5 (lima) orang hakim yang diusulkan dan dipanggil untuk mengikuti prosedur yang diterapkan oleh biro SDM Kementerian Keuangan. Kelima orang calon tersebut kemudian mengikuti rangkaian fit and proper test hingga akhirnya terpilih 2 (dua) orang hakim yang akan menjabat sebagai wakil ketua. Dalam proses tersebut, narasumber mengungkapkan tidak mengetahui secara pasti informasi maupun kriteria yang digunakan untuk memilih 5 (lima) orang hakim agar mengikuti proses di Kementerian Keuangan.

Berdasarkan mekanisme yang telah diuraikan, independensi Pengadilan Pajak nampaknya belum terwujud secara paripurna. Mekanisme yang ada belum mendukung independensi Pengadilan Pajak secara institusional dan personal. Secara institusional, keterlibatan Menteri Keuangan dalam internal Pengadilan Pajak untuk memilih Ketua dan Wakil Ketua membuat organisasi seolah tidak independen. Hal ini didukung berdasarkan penelitian yang dilakukan oleh Wijayanti (2018), meskipun salah satu fokus penilaian yakni pada proses rekrutmen hakim. Selain itu, jika kembali merujuk pada konsep independensi personal yang diungkapkan oleh Sulistiyono (2018), sistem promosi hakim Pengadilan Pajak masih cukup abu-abu dan berpotensi belum sepenuhnya terdepolitisasi dari keterlibatan langsung Menteri Keuangan. Selain itu, tidak dijumpainya ketentuan lebih lanjut mengenai syarat dan mekanisme pengusulan Ketua dan Wakil Ketua dapat menimbulkan ketidakpastian karier bagi hakim Pengadilan Pajak. Meskipun dalam pandangan pemerintah disebutkan bahwa seluruh hakim memiliki kesempatan yang sama untuk dipilih menjadi Ketua dan Wakil Ketua Pengadilan Pajak, tidak ada pedoman atau dasar penilaian yang jelas untuk menjamin kesempatan tersebut. Dengan demikian, dapat disimpulkan bahwa hakim Pengadilan Pajak masih 
belum memperoleh jaminan independensi personal, khususnya dalam hal karier untuk menjadi Ketua dan Wakil Ketua Pengadilan Pajak.

Pengadilan Pajak memang memiliki kekhususan. Pengadilan Pajak menangani sengketa pajak sebagai sengketa khusus, sehingga diperlukan keahlian khusus. Agar dapat menjadi hakim Pengadilan Pajak, terdapat syarat yang harus dipenuhi, salah satunya diatur dalam UU Pengadilan Pajak pasal 9 ayat (1) huruf $f$, yang mensyaratkan bahwa calon Hakim Pengadilan Pajak harus mempunyai keahlian di bidang perpajakan dan berijazah sarjana hukum atau sarjana lain.

Oleh karena itu, fakta bahwa hakim Pengadilan Pajak sebagian besar berasal dari Kementerian Keuangan dapat dipandang wajar karena kompetensi yang dimilikinya. Selain itu, keterlibatan Kementerian Keuangan dalam proses pengusulan Ketua dan Wakil Ketua Pengadilan Pajak juga dapat dipahami karena memiliki kemampuan atau akses untuk menilai calon pimpinan Pengadilan Pajak. Namun, agar kekuasaan kehakiman dapat tetap berjalan independen dan imparsial, skema check and balances mutlak diperlukan dan nampak diwujudkan dengan melibatkan Mahkamah Agung sebagai induk dari lembaga peradilan di Indonesia.

Walau demikian, kekhususan ketentuan Pengadilan Pajak ini dikritisi oleh Jan (2012) yang membandingkan dengan ketentuan UU Kekuasaan Kehakiman. Pengadilan dan hakim dipandang harus independen baik terhadap cabang kekuasaan yang lain maupun terhadap pihak-pihak yang berperkara. Kekuasaan kehakiman yang merdeka menjadi ciri substantif dari sebuah negara hukum demokratis (democratische rechtsstaat). Keterlibatan Menteri Keuangan dianggap tidak mencerminkan semangat konstitusi dan keterpaduan sistem peradilan. Argumen tersebut juga diperkuat oleh Wijayanti (2018) bahwa karakteristik khusus Pengadilan Pajak telah mengarahkan pada pembentukan opini Wajib Pajak bahwa Pengadilan Pajak tidaklah independen.

$\mathrm{Hal}$ tersebut sangat jelas pada proses rekrutmen hakim serta pengusulan Ketua dan Wakil Ketua Pengadilan Pajak. Berdasarkan pendapat yang diungkapkan oleh Putri (2019), proses rekrutmen hakim akan memengaruhi kualitas keputusan hakim. Namun demikian, mereka sepakat bahwa keberadaan Pengadilan Pajak yang sebagian masih dalam lingkup eksekutif dianggap tidak begitu memengaruhi hakim dalam memutus sengketa karena hakim menilai berdasarkan pembuktian di persidangan.

Berdasarkan uraian tersebut, maka dapat disimpulkan bahwa mekanisme pengusulan Ketua dan Wakil Ketua Pengadilan Pajak yang pernah berjalan masih belum menciptakan kepastian hukum terutama dalam hal karier bagi Hakim Pengadilan Pajak. Dengan merujuk pada prasyarat independensi personal menurut Sulistiyono (2018), independensi personal hakim juga belum terjamin seluruhnya. Sementara itu, upaya untuk menjaga independensi institusional Pengadilan Pajak sebenarnya diwujudkan dengan adanya skema check and balances pada proses pengusulan Ketua dan Wakil Ketua Pengadilan Pajak yang memerlukan persetujuan bersama antara Menteri Keuangan dan Ketua Mahkamah Agung.

\subsection{Ketentuan Pengusulan Ketua dan Wakil Ketua Pengadilan Pajak Setelah Putusan Mahkamah Konstitusi.}

Pasca Putusan Mahkamah Konstitusi, Ketua dan Wakil Ketua Pengadilan Pajak dipilih dari dan oleh Hakim Pengadilan Pajak. Untuk melaksanakan amar Putusan Mahkamah Konstitusi tersebut, dibentuk pengaturan mengenai mekanisme pemilihan Ketua Pengadilan Pajak dalam Keputusan Ketua Pengadilan Pajak Nomor KEP-01/PP/2021 tentang Tata Tertib Pemilihan Ketua Pengadilan Pajak. Berdasarkan KEP01/PP/2021, mekanisme pemilihan Ketua Pengadilan Pajak dilakukan dalam 2 (dua) tahap dengan mekanisme pemungutan suara. Tahap pertama dilaksanakan untuk memilih Calon Ketua Pengadilan Pajak dari para hakim yang telah memenuhi syarat. Setelah Calon Ketua terpilih, tahap selanjutnya yaitu memilih Ketua Pengadilan Pajak berdasarkan namanama Calon Ketua yang terpilih pada tahap pertama.

a. Tahap Pemilihan Calon Ketua Pengadilan Pajak

Seluruh Hakim Pengadilan Pajak pada dasarnya berhak untuk dipilih menjadi Calon Ketua Pengadilan Pajak sepanjang telah memenuhi persyaratan yang telah ditetapkan. Hakim yang dapat dipilih untuk menjadi Calon Ketua Pengadilan Pajak harus memenuhi persyaratan berikut.

- Telah diangkat sebagai Hakim Ketua.

- Berusia setinggi-tingginya 64 (enam puluh empat) tahun pada saat pemilihan.

- Tidak sedang menjabat sebagai Ketua Pengadilan Pajak.

- Hadir secara langsung dalam rapat pemilihan, kecuali berhalangan karena sedang menjalani isolasi mandiri/perawatan karena COVID-19.

Panitia Pemilihan kemudian akan membuat daftar Calon Ketua Pengadilan Pajak yang berhak dipilih berdasarkan nama-nama hakim yang telah memenuhi persyaratan di atas. Daftar nama tersebut menjadi dasar pembuatan surat suara. Setiap Hakim Pengadilan Pajak selanjutnya memilih Calon Ketua yang telah ditetapkan sesuai daftar nama tersebut.

b. Tahap Pemilihan Ketua Pengadilan Pajak

Setelah Calon Ketua Pengadilan Pajak terpilih dari tahap pertama, pada tahap kedua ini para Calon tersebut akan dipilih kembali oleh para Hakim untuk menentukan Ketua Pengadilan Pajak terpilih. Pada tahap ini, Calon Ketua yang memperoleh suara terbanyak akan ditetapkan sebagai Ketua Pengadilan Pajak terpilih.

Berdasarkan mekanisme yang telah diuraikan di atas, adanya Keputusan Ketua Pengadilan Pajak yang mengatur tata cara pemilihan dan kriteria untuk dapat dicalonkan menjadi Ketua dapat menjadi pedoman bagi hakim Pengadilan Pajak ketika hendak menyelenggarakan pemilihan Ketua Pengadilan Pajak pada periode-periode berikutnya. Selain itu, adanya ketentuan yang mengatur bahwa seluruh hakim Pengadilan Pajak berpeluang untuk memilih dan dipilih telah memberikan jaminan kepastian hukum 
daripada mekanisme yang pernah berjalan sebelumnya. Aspek kepastian hukum ini berkaitan erat dengan kepastian karier bagi hakim untuk dapat dipilih menjadi pimpinan Pengadilan Pajak. Sebagaimana pertimbangan hukum Majelis Hakim Konstitusi, para hakim dianggap sudah saling mengenal akan kemampuan dan karakter masing-masing. Oleh karenanya, para hakim seharusnya mampu menentukan pemimpinnya sendiri tanpa keterlibatan pihak eksternal. Hal tersebut juga diperkuat dengan pendapat narasumber N4. Penilaian level of integrity dari para calon ketua dan wakil ketua pada dasarnya sudah dilakukan berdasarkan kegiatan dan pekerjaan sehari-hari. Dengan demikian, Menteri Keuangan tidak perlu terlibat secara langsung dan para hakim dapat menentukan Pimpinan Pengadilan Pajak secara mandiri.

Kebebasan hakim untuk menentukan pemimpinnya sendiri dapat dimaknai melalui tafsir atas frasa ". . . dipilih dari dan oleh hakim ..." dalam amar putusan Mahkamah Konstitusi. Menurut wawancara dengan N4, kata "dari" bermakna asal atau background dari orang yang akan dicalonkan, yakni calon dipilih dari para hakim Pengadilan Pajak. Sementara itu, kata "oleh" berarti penyelenggara atau pemilih, yakni diselenggarakan oleh hakim Pengadilan Pajak. Oleh karena itu, frasa "dari dan oleh" bermakna bahwa berdasarkan amar Putusan Mahkamah Konstitusi hakim Pengadilan Pajak memperoleh wewenang tanpa syarat untuk merumuskan kriteria dan cara menentukan pemimpinnya sendiri. Dengan demikian, amar putusan Mahkamah Konstitusi telah menunjukkan upaya untuk mewujudkan independensi personal sesuai konsep yang digagas oleh Sulistiyono (2018). Kebebasan hakim untuk menentukan pemimpinnya sejalan dengan konsep mekanisme pengangkatan dan promosi hakim yang terdepolitisasi dari campur tangan pihak lain.

Pembatasan wewenang Menteri Keuangan untuk terlibat lebih jauh dalam proses pemilihan Ketua dan Wakil Ketua Pengadilan Pajak dapat disebut sebagai upaya untuk menjaga marwah Pengadilan Pajak sebagai lembaga peradilan di Indonesia. Selaras dengan konsep pemisahan kekuasaan yang diuraikan oleh Asshiddiqie (2006a), pembatasan kekuasaan dengan cara memisahkan antar cabang kekuasaan bertujuan untuk mencegah terjadinya kesewenangwenangan. Dengan diterapkannya sistem pemisahan kekuasaan dan prinsip checks and balances antar lembaga negara yang berpuncak pada tiga cabang kekuasaan, maka terdapat hubungan saling mengontrol dan mengimbangi satu sama lain. Apabila dikaitkan dalam konteks Pengadilan Pajak ini, pemisahan peran yudikatif dan adanya jaminan independensi berperan penting untuk menciptakan keadilan dalam mengatasi sengketa pajak. Meskipun Jan (2012), Wijayanti (2018), Putri (2019), dan Kurniawan (2020) menyimpulkan bahwa independensi hakim dalam memutus sengketa pajak tidak dipengaruhi oleh dualisme pembinaan, secara filosofi kehadiran lembaga peradilan tetap tidak dapat dipisahkan dari konsep pemisahan kekuasaan dan teori independensi peradilan. Tanpa adanya dasar filosofis akan kebebasan Pengadilan Pajak, maka para pihak yang bersengketa belum sepenuhnya memperoleh rasa kepastian hukum. Oleh karena itu, putusan Mahkamah Konstitusi ini secara tidak langsung menjadi cukup penting bagi para pencari keadilan.

Perubahan ketentuan pemilihan Ketua dan Wakil Ketua Pengadilan Pajak menjadi dipilih dari dan oleh hakim Pengadilan Pajak menjadi serupa dengan mekanisme pemilihan Ketua Mahkamah Agung. Merujuk pada ketentuan pasal 8 ayat (7) UndangUndang Nomor 3 Tahun 2009 tentang Perubahan Kedua atas Undang-Undang Nomor 14 Tahun 1985 tentang Mahkamah Agung, diatur bahwa "Ketua dan Wakil Ketua Mahkamah Agung dipilih dari dan oleh hakim agung dan ditetapkan oleh Presiden." Dengan mengambil contoh mekanisme pemilihan Ketua Mahkamah Agung pada tahun 2020 sesuai Keputusan Ketua Mahkamah Agung No. 96/KMA/SK/IV/2020 tentang Peraturan Tata Tertib Pemilihan Ketua Mahkamah Agung Republik Indonesia, cara pemilihan calon Ketua Pengadilan Pajak secara garis besar serupa dengan Ketua Mahkamah Agung. Pada mekanisme pemilihan Ketua Mahkamah Agung, setiap Hakim Agung memiliki hak yang sama untuk memilih dan dipilih. Pemilihan Ketua juga dilakukan dengan 2 (dua) tahap, yakni tahap pemilihan Calon Ketua dan tahap pemilihan Ketua.

Namun, apabila ketentuan pemilihan Ketua dan Wakil Ketua di Pengadilan Pajak dibandingkan dengan lingkungan Peradilan Tata Usaha Negara (TUN) dan lingkungan Peradilan Umum, ketentuan yang ada ternyata berbeda. Baik pada Pengadilan Negeri, Pengadilan Tinggi, Pengadilan Tata Usaha Negara, dan Pengadilan Tinggi Tata Usaha Negara, Ketua dan Wakil Ketua Pengadilan diangkat dan diberhentikan oleh Ketua Mahkamah Agung. Ketentuan pada lingkungan Peradilan TUN telah diatur dalam pasal 16 ayat (2) Undang-Undang Nomor 51 Tahun 2009 tentang Perubahan Kedua Atas Undang-Undang Nomor 5 Tahun 1986 tentang Peradilan Tata Usaha Negara. Sementara itu, pada lingkungan Peradilan Umum diatur dalam pasal 16 ayat (2) Undang-Undang Nomor 49 Tahun 2009 tentang Perubahan Kedua atas Undang-Undang Nomor 2 Tahun 1986 tentang Peradilan Umum.

Meskipun berbeda, secara filosofi ketentuan tersebut telah mencerminkan adanya kemerdekaan kekuasaan kehakiman yang bebas dari campur tangan eksekutif. Jika merujuk pada UU No. 5 tahun 1986 dan UU No. 2 tahun 1986, masih dimungkinkan keterlibatan Menteri Kehakiman dalam pengangkatan Ketua dan Wakil Ketua Pengadilan di lingkungan Peradilan TUN dan Peradilan Umum. Pasca perubahan, kewenangan tersebut diserahkan sepenuhnya kepada Ketua Mahkamah Agung. Penyerahan kewenangan secara penuh kepada yudikatif menunjukkan adanya upaya untuk melaksanakan konsep pemisahan kekuasaan dan menciptakan independensi kekuasaan kehakiman. Dengan demikian, adanya penyerahan kewenangan 
Menteri Keuangan kepada hakim Pengadilan Pajak pada proses pemilihan Ketua dan Wakil Ketua Pengadilan Pajak pasca putusan Mahkamah Konstitusi pun dapat dimaknai positif, yakni untuk menciptakan independensi dan keselarasan dengan lembaga peradilan lainnya.

Meski demikian, berdasarkan wawancara dengan N3, N4, dan N5, diketahui bahwa mekanisme pemilihan Ketua Pengadilan Pajak rupanya masih dimungkinkan adanya perubahan pada periodeperiode berikutnya dengan substansi yang kemungkinan tetaplah sama. Dengan adanya peluang untuk dilakukan perubahan, hal tersebut bagus untuk menyesuaikan dengan situasi yang ada serta dapat mengakomodir berbagai usulan hakim yang mungkin baru bergabung di masa yang akan datang.

Sebaiknya, pertama-tama perlu ditetapkan sebuah peraturan atau ketentuan umum dan bersifat tetap, misalnya mengenai kriteria untuk menjadi pimpinan dan tata cara pemilihannya. Sementara untuk ketentuan-ketentuan yang bersifat teknis, seperti pembentukan panitia, jangka waktu pemilihan, dan lain-lain dapat diubah sesuai dengan kebutuhan pada masa pemilihan hendak diselenggarakan. Harapannya, dengan pembuatan mekanisme yang demikian hakim Pengadilan Pajak sudah memiliki prosedur yang pasti sehingga tidak perlu mengubah atau membuat ketentuan baru. Dengan demikian, proses pemilihan dapat berjalan lebih efisien dan tidak terlalu banyak menghabiskan waktu dan tenaga.

\subsection{Pandangan Hakim Pengadilan Pajak terkait Mekanisme Pemilihan Ketua dan Wakil Ketua Pengadilan Pajak Sebelum dan Setelah Putusan Mahkamah Konstitusi.}

Terhadap mekanisme sebelum Putusan Mahkamah Konstitusi, berdasarkan wawancara dengan narasumber N3, N4, dan N5, memang diakui bahwa ketentuan dalam pasal 8 ayat (2) UU Pengadilan Pajak tidak memberikan ketentuan pelaksanaan yang rinci dan jelas. Para narasumber tidak mengetahui secara rinci proses yang terjadi di dalamnya. Sebagaimana diungkapkan oleh narasumber N3, narasumber hanya sebatas mengetahui bahwa menurut ketentuan undangundang, Menteri Keuangan mengusulkan Ketua dan Wakil Ketua untuk diangkat Presiden setelah mendapat persetujuan dari MA. Hal tersebut juga disepakati oleh narasumber N4 dan N5.

Berdasarkan pandangan para narasumber, secara umum mekanisme pemilihan Ketua dan Wakil Ketua yang tidak memberikan ketentuan rinci menciptakan ketidakpastian dan keresahan bagi para hakim Pengadilan Pajak. Hakim mengetahui ketentuan undang-undang bahwa pimpinan "dipilih dari para hakim Pengadilan Pajak", namun mekanisme pemilihannya tidak diketahui. Hal tersebut tentunya sejalan dengan argumen Para Pemohon uji materi yang menyatakan demikian.

"Bahwa Pasal 5 ayat (2) dan Pasal 8 ayat (2) UU Pengadilan Pajak mengaburkan pemahaman mengenai kekuasaan kehakiman yang merdeka yang seharusnya tidak berada pada pengaruh atau potensi pengaruh, pikiran, atau perasaan yang langsung maupun tidak langsung menyebabkan hakim pengadilan pajak berada pada ketidakpastian hukum dan kemerdekaannya. Hakim pengadilan pajak memang tidak dikurangi kemerdekaannya dalam mengambil putusan, meskipun masih berada dalam dua pembinaan instansi, . . . . Adapun berkurangnya kemerdekaan hakim di sini adalah karena adanya kewenangan Menteri Keuangan untuk mengusulkan Ketua dan Wakil Ketua yang tidak transparan (tanpa parameter yang jelas) berpotensi mereduksi ketentuan Pasal 5 ayat (3) UU Pengadilan Pajak." (Putusan MK No. 10/PUU-XVIII/2020, p. 10).

Meski demikian, adanya keterlibatan Menteri Keuangan pada mekanisme sebelum putusan Mahkamah Konstitusi rupanya tetap dapat dilihat dari dua sisi. Narasumber N4 menyatakan sisi positif maupun negatif jika dilihat dari dua sisi. Sisi positifnya bagi Kementerian Keuangan, mekanisme yang ada mampu menegaskan kedudukan Kementerian Keuangan sebagai pembina organisasi Pengadilan Pajak sesuai Pasal 5 ayat (2) UU Pengadilan Pajak. Sementara itu di sisi Pengadilan Pajak, mekanisme yang ada justru berpotensi menimbulkan dampak negatif bagi hakim Pengadilan Pajak, yang berkaitan dengan ketidakpastian karier hakim, sekaligus secara tidak langsung persepsi para pihak yang bersengketa atas putusan Pengadilan Pajak.

Apabila dikaitkan dengan independensi putusan, mantan Wakil Ketua Pengadilan Pajak, Sartono (2019, dikutip dalam Kurniawan, 2020) mengungkapkan bahwa meskipun masih terdapat dualisme pembinaan Pengadilan Pajak, hakim Pengadilan Pajak secara individual berupaya untuk tetap independen dan menghasilkan putusan yang objektif berdasarkan peraturan perundang-undangan yang berlaku. Hal tersebut dibuktikan pada persentase kemenangan Kementerian Keuangan yang kurang dari 50\% berdasarkan data yang tersaji pada Tabel 1.2 dan Tabel 1.3. Oleh karena itu, permasalahan mengenai keterlibatan Menteri Keuangan menurut Kurniawan (2020) lebih dipandang sebagai hambatan potensial terhadap independensi Pengadilan Pajak secara institusional bukan independensi hakim secara individual.

Pasca putusan Mahkamah Konstitusi, mekanisme pemilihan Ketua dan Wakil Ketua Pengadilan Pajak ditentukan oleh para hakim Pengadilan Pajak tanpa keterlibatan Kementerian Keuangan. Dengan adanya ketentuan tersebut, narasumber N3 berpandangan bahwa mekanisme yang ada menjadi "demokratis dan secara filosofis setiap hakim juga memiliki kesempatan untuk memilih dan dipilih sebagai Ketua dan/atau Wakil Ketua." Pendapat tersebut juga didukung oleh narasumber N5 yang menyatakan sebagai berikut.

"Berdasar putusan Mahkamah Konstitusi maka hakimhakim lebih memiliki kewenangan dan kebebasan untuk menentukan, sehingga aspirasinya bisa lebih tersalurkan ... Jadi poinnya, hakim sekarang bisa berpartisipasi, ikut terlibat sejak merumuskan tata tertibnya sampai proses pemilihannya."

Lebih lanjut, dengan merujuk pada karakteristik putusan Mahkamah Konstitusi, narasumber N4 memaparkan pandangan berikut. 
"Hasil pengujian kemarin menunjukkan bahwa bunyi pasal UU Pengadilan Pajak itu tidak sesuai dengan UUD 45 . . . karena mengurangi independensi Pengadilan Pajak sebagai lembaga yudikatif. Nah dengan mengikuti bunyi atau ketentuan yang telah diubah oleh Mahkamah Konstitusi, akhirnya ketua dan wakil ketua ... . pasti ada legitimasinya, yaitu sesuai dengan undang-undang."

Persetujuan para hakim mengenai mekanisme pemilihan Ketua dan Wakil Ketua Pengadilan Pajak secara lebih demokratis pada akhirnya selaras dengan konsep kekuasaan kehakiman yang merdeka dan independensi personal yang dipaparkan oleh Sulistiyono (2018). Kebebasan untuk menentukan pemimpinnya sendiri membuka peluang aspirasi bagi hakim dan kesempatan yang sama untuk dapat dipilih sebagai pemimpin Pengadilan Pajak. Adanya mekanisme pemilihan yang sehat menjadi harapan agar independensi Pengadilan Pajak benar-benar terjaga dan menjamin para hakim dalam memeriksa dan memutus sengketa pajak.

\subsection{Pandangan Akademisi terkait Mekanisme Pemilihan Ketua dan Wakil Ketua Pengadilan Pajak Sebelum dan Setelah Putusan Mahkamah Konstitusi} Merujuk pada ketentuan pasal 8 ayat (2) UU Pengadilan Pajak, Ketua dan Wakil Ketua Pengadilan Pajak dipilih dari para hakim yang diusulkan Menteri Keuangan dengan persetujuan Ketua Mahkamah Agung untuk diangkat. Di dalam penjelasan pasal, hanya disebutkan "cukup jelas" dan tidak dijumpai adanya suatu aturan turunannya. Menanggapi mekanisme yang telah berjalan, baik narasumber N1 maupun N2 sepakat bahwa tidak ada interpretasi lain apabila pasal tersebut ditafsirkan sehingga Menteri Keuangan memiliki kewenangan untuk menentukan mekanisme yang digunakan.

Lebih lanjut, atas mekanisme pengusulan Ketua dan Wakil Ketua Pengadilan Pajak yang diajukan oleh ketua dan wakil ketua eksisting, N2 menambahkan pendapat berikut:

"Karena ini lebih ke masalah organisasi, jadi mekanismenya lebih karena kebiasaan saja. Jadi dapat dimaklumi jika ketua eksisting yang akan mengusulkan karena dianggap mengetahui kompetensi hakimhakim untuk memimpin organisasi Pengadilan Pajak. Kemudian, dari sisi Menteri Keuangannya akan melihat track record, leadership, dan kompetensi dari calon hakimnya. Tetapi, keputusan persetujuan tetap ada di tangan Mahkamah Agung. Sebenarnya karena posisinya ada di dua kamar, jadi nggak murni ya, ada kerja sama antara Kementerian Keuangan sebagai pelaksana kekuasaan eksekutif dengan Mahkamah Agung yang memiliki kekuasaan kehakiman atau yudisial. Jadi menurut saya, ketentuan dan mekanisme pengusulan sebelum Putusan MK ini adalah konsekuensi dari dua kamar tadi."

Pendapat tersebut sejalan dengan kondisi Pengadilan Pajak yang masih mengalami dualisme pembinaan. Karena hingga saat ini, ketentuan dalam UU Pengadilan Pajak masih membagi pembinaan
Pengadilan Pajak di bawah Mahkamah Agung dan Kementerian Keuangan.

Pasca putusan Mahkamah Konstitusi, mekanisme pengusulan Ketua dan Wakil Ketua Pengadilan Pajak mengalami perubahan. Sebagaimana yang diungkapkan narasumber N2 putusan tersebut justru perlu dipandang sebagai permasalahan mengenai jalannya organisasi. Hal ini didasarkan pada pertimbangan hukum Mahkamah Konstitusi yang menyatakan bahwa para hakim dianggap yang paling mengetahui kompetensi dan kemampuan rekanrekannya. Argumen tersebut diperkuat oleh tanggapan N1 berikut:

"adanya putusan MK ini memberikan titik terang dan kejelasan bahwa Menkeu berfungsi memberikan pembinaan administrasi dan organisasi saja... menteri tidak ikut campur lebih dalam pada pemilihan Ketua Pengadilan Pajaknya. Jadi, menteri harusnya mengadministrasikan saja pengusulannya. Sedangkan para hakim silahkan untuk membuat mekanisme bagaimana mereka memilih ketua di antara mereka sendiri ... Tetapi, usulannya nanti tetap harus melalui Menkeu dulu selaku pembina administrasi dan organisasi."

Lebih lanjut, adanya putusan Mahkamah Konstitusi juga dapat dikatakan menghindarkan hakim dari perasaan parkewuh dalam memutus sengketa pajak mengingat adanya keterlibatan Kementerian Keuangan dalam proses rekrutmennya. Jadi berdasarkan pendapat tersebut dapat disimpulkan bahwa adanya putusan Mahkamah Konstitusi sebenarnya memberikan kejelasan bahwa pembinaan organisasi oleh Kementerian Keuangan tidak termasuk mengusulkan Ketua dan Wakil Ketua Pengadilan Pajak secara langsung. Pengadilan Pajak kini dapat memilih ketua dan wakil ketuanya sendiri. Oleh karena itu, permasalahan mengenai jalannya organisasi pada akhirnya bersinggungan dengan konsep independensi personal yang telah diuraikan sebelumnya.

Sehubungan dengan independensi hakim dalam memutus sengketa pajak, putusan Mahkamah Konstitusi dianggap tidak terlalu berpengaruh terhadap independensi hakim. Hal ini karena hakim pada dasarnya dipandang sudah cukup independen dalam memutus sengketa pajak. Berdasar pengalaman mengikuti persidangan, N2 mengungkapkan bahwa:

"Sebagai contoh, salah satu yang dipermasalahkan dalam putusan MK itu adalah adanya surat edaran (SE) Ketua Pengadilan Pajak . . . Selama ini berdasarkan pengalaman saya mengikuti sidang terkait sengketa pasal 36 ayat (1) huruf b UU KUP, hakim memiliki kebebasan untuk (menentukan) apakah dalam persidangan akan masuk ke materi atau tidak. Artinya, dalam memutus perkara independensi hakim tetap terjaga meskipun ada SE Ketua Pengadilan Pajak tadi." Apabila melihat rasio kemenangan/kekalahan sengketa pajak pada Tabel 1.2, Tabel 1.3, para pimpinan pengadilan pajak, dan pemohon uji materi ${ }^{2}$, terlihat bahwa tingkat kemenangan Kementerian Keuangan (dalam hal ini DJP dan DJBC) sebagai terbanding/tergugat rata-rata di bawah 50\%. Artinya,

\footnotetext{
${ }^{2}$ Mahkamah Konstitusi Republik Indonesia, Putusan 
sebagian besar sengketa dimenangkan oleh wajib pajak. Pernyataan narasumber ini tentu makin menguatkan pernyataan penelitian yang dilakukan oleh Jan (2012), Wijayanti (2018), Putri (2019), dan Kurniawan (2020) yang berpandangan bahwa dualisme pembinaan Pengadilan Pajak tidak berpengaruh pada independensi dan kualitas putusan hakim. Berangkat dari fakta tersebut, N1 pun justru menegaskan bahwa diperlukan penelitian lebih lanjut mengenai penyebab rendahnya tingkat kemenangan Kementerian Keuangan.

Sebagai tindak lanjut dari putusan Mahkamah Konstitusi, diperlukan suatu ketentuan yang mengatur mekanisme pengusulan Ketua dan Wakil Ketua Pengadilan Pajak. Oleh karenanya penulis juga berusaha menggali pendapat akademisi mengenai mekanisme pengusulan Ketua dan Wakil Ketua Pengadilan Pajak. Berdasarkan wawancara yang dilakukan, setidaknya terdapat 2 (dua) pokok pikiran yang dikemukakan. Pertama, diperlukannya upaya harmonisasi pembagian peran dalam proses pengusulan Ketua dan Wakil Ketua Pengadilan Pajak antara Pengadilan Pajak dengan Kementerian Keuangan. Kedua, diperlukan penyelarasan mekanisme pengusulan Ketua dan Wakil Ketua Pengadilan Pajak berdasarkan best practice di lingkungan peradilan lainnya.

Tentunya jika melihat pada ketentuan mekanisme yang telah ada, proses pada sisi Pengadilan Pajak memang telah diatur dengan pedoman tersendiri. Hanya saja, diperlukan penelitian lebih lanjut mengenai proses pada sisi Menteri Keuangan. Salah satu poin untuk menindaklanjuti hasil dari proses di Pengadilan Pajak yakni mengenai proses permintaan persetujuan kepada Mahkamah Agung. Narasumber N1 berpandangan pengaturan tersebut memang sangat penting mengingat Pengadilan Pajak merupakan pengadilan khusus yang memiliki keunikan dengan adanya peran Kementerian Keuangan sebagai pembina organisasi dan administrasi Pengadilan Pajak. Dengan adanya pengaturan pada kedua sisi, maka batas-batas sampai sejauh mana masing-masing institusi berperan dan pada titik mana kedua institusi saling berkoordinasi akan semakin jelas.

Selain pengaturan mekanisme pada masingmasing institusi, diperlukan juga upaya untuk melihat best practice di lingkungan peradilan lain. Dengan merujuk pada pertimbangan hukum Mahkamah Konstitusi, N2 berpandangan sebagai berikut.

"idealnya perlu melihat mekanisme pemilihan ketua dan wakil ketua di lembaga pengadilan lainnya. . . . Nah ini yang kemarin tidak begitu terlihat jelas. Dasar pertimbangan Mahkamah Konstitusi masih berdasarkan aspek filosofis, yakni siapa yang dianggap paling mengetahui dan mengenal calon ketua dan wakil ketua ..."

Pada pertimbangan hukumnya, Mahkamah memang tidak menyebutkan secara jelas apakah keputusan tersebut didasarkan pada pertimbangan kelaziman di lembaga peradilan lainnya atau tidak. Adanya putusan Mahkamah Konstitusi yang mengatur bahwa pemilihan Ketua dan Wakil Ketua Pengadilan Pajak dipilih dari dan oleh para hakim secara implisit berdampak pada diterapkannya mekanisme pemungutan suara atau voting. Adanya pandangan untuk menyelaraskan mekanisme dengan peradilan lainnya juga tidak dapat dilepaskan dengan adanya aspek keseragaman pada tubuh organisasi kekuasaan kehakiman. Namun karena posisi pengadilan pajak yang dianggap masih belum murni karena adanya dualisme, maka perbedaan proses tersebut masih dapat dimaklumi jika dilihat dari sudut pandang kekhususan peraturan perundang-undangan yang membentuknya. Oleh karena itu, pendapat N2 serupa dengan Jan (2012) yang menyarankan agar Pengadilan Pajak dapat selaras dengan lembaga peradilan lainnya dalam satu atap murni di bawah Mahkamah Agung, diperlukan perubahan terhadap UU Pengadilan Pajak. Kebijakan satu atap bertujuan untuk menjaga dan memastikan agar hakim dapat terbebas dari pengaruh apa pun dalam memeriksa dan memutus sengketa pajak.

\section{KESIMPULAN DAN SARAN}

\subsection{Kesimpulan}

Berdasarkan pembahasan di atas mengambil beberapa kesimpulan sebagai berikut:

a. Sebelum Putusan Mahkamah Konstitusi No. 10/PUU-XVIII/2020, mekanisme pemilihan Ketua dan Wakil Ketua Pengadilan Pajak hanya berdasarkan pasal 8 ayat (2) UU Pengadilan Pajak. Sesuai ketentuan, Ketua dan Wakil Ketua diangkat oleh Presiden dari para Hakim yang diusulkan Menteri setelah mendapat persetujuan Ketua Mahkamah Agung.

b. Pasca putusan Mahkamah Konstitusi No. 10/PUUXVIII/2020, Ketua dan Wakil Ketua Pengadilan Pajak menjadi dipilih dari dan oleh para hakim. Dengan demikian, para hakim Pengadilan Pajak memiliki kewenangan untuk menentukan pimpinan Pengadilan Pajak. Melalui mekanisme yang baru, kriteria untuk menjadi Ketua dan Wakil Ketua Pengadilan Pajak ditentukan berdasarkan kesepakatan dari para hakim. Pada awal tahun 2021, para hakim memilih Ketua Pengadilan Pajak dengan cara pemungutan suara yang diatur dengan Keputusan Ketua Pengadilan Pajak No. KEP01/PP/2021.

c. Berdasarkan pandangan hakim yang menjadi narasumber, mekanisme pemilihan Ketua dan Wakil Ketua Pengadilan Pajak sebelum putusan Mahkamah Konstitusi No.10/PUU-XVIII/2020 masih cukup abu-abu dan tidak begitu transparan. Pasca putusan Mahkamah Konstitusi, para narasumber sepakat bahwa mekanisme yang ada menjadi lebih transparan, jelas, dan demokratis. Para hakim memperoleh jaminan kepastian dan memiliki kewenangan untuk merumuskan kriteria dan proses yang akan dilakukan dalam memilih Ketua dan Wakil Ketua Pengadilan Pajak.

d. Berdasarkan wawancara dengan para narasumber yang memiliki latar belakang akademisi, UU Pengadilan Pajak tidak memberikan penafsiran lain, sehingga para narasumber berpandangan 
bahwa Menteri Keuangan diberikan kewenangan sesuai undang-undang..

e. Sebagai tindak lanjut, idealnya diperlukan upaya harmonisasi peraturan pada masing-masing proses, yakni proses pemilihan di Pengadilan Pajak dan proses lanjutan oleh Kementerian Keuangan. Selain itu, disarankan terdapat penyelarasan mekanisme di Pengadilan Pajak dengan mekanisme pada lembaga peradilan lain. Dengan demikian, mekanisme pengusulan Ketua dan Wakil Ketua Pengadilan Pajak pasca putusan Mahkamah Konstitusi dapat lebih menciptakan kepastian hukum.

\subsection{Saran}

a. Mengingat kekhususan Pengadilan Pajak yang berada di Kementerian Keuangan secara administrative dalam proses pengusulan Ketua dan Wakil Ketua Pengadilan Pajak perlu kiranya menggunakan kreteria dengan mengedapanan intergritas, profesionalisme dan independensi sebagai Ketua dan Wakil Ketua Pengadilan.

b. Kreteria yang jelas akan memberikan jaminan independensi dan kepastian hukum bagi para pihak yang bersengketa.

\section{IMPLIKASI DAN KETERBATASAN}

Penulis menyadari masih adanya keterbatasan dalam penelitian ini, yaitu:

a. Pembahasan masih terfokus pada proses pemilihan ketua dan wakil ketua dari sisi Pengadilan Pajak. Diperlukan penelitian lebih lanjut mengenai proses lanjutan di Kementerian Keuangan agar hasil penelitian dapat lebih komprehensif.

b. Sumber pembahasan hanya diperoleh dari studi literatur dan wawancara narasumber secara daring. Penulis tidak melakukan observasi secara langsung mengenai proses pemilihan ketua di Pengadilan Pajak. Selain itu, untuk melengkapi hasil penelitian akan lebih baik jika penelitian selanjutnya dapat menghadirkan narasumber yang terkait langsung dari Kementerian Keuangan.

c. Penilaian independensi masih terfokus pada independensi lembaga peradilan secara institusional berdasarkan tinjauan yuridis karena keterbatasan waktu penelitian.

\section{PENGHARGAAN (ACKNOWLEDGEMENT)}

Penulis menyampaikan terima kasih kepada Bapak Supriyadi, S.E., M.Si., selaku dosen pembimbing yang dengan sabar telah membimbing penulis dalam menyusun penelitian ini hingga akhirnya dapat terselesaikan dengan baik.

Penulis juga menyampaikan terima kasih kepada para narasumber, yakni hakim Pengadilan Pajak dan akademisi dari Politeknik Keuangan Negara STAN, yang telah berkenan untuk menjadi narasumber dan memberikan berbagai pandangan dalam penyusunan penelitian ini.
Penulis bertanggung jawab sepenuhnya terhadap hasil penelitian termasuk error yang kemungkinan terjadi.

\section{DAFTAR PUSTAKA (REFERENCES)}

Asshiddiqie, J. (2006a). Konstitusi dan Konstitusionalisme Indonesia. Sekretariat Jenderal dan Kepaniteraan Mahkamah Konstitusi RI.

Asshiddiqie, J. (2006b). Pengantar Ilmu Hukum Tata Negara Jilid II. Sekretariat Jenderal dan Kepaniteraan Mahkamah Konstitusi RI.

Direktorat Jenderal Pajak RI. (2021). Laporan Kinerja Tahun 2020.

Direktorat Jenderal Pajak RI. (2020). Laporan Kinerja Tahun 2019.

Direktorat Jenderal Pajak RI. (2019). Laporan Kinerja Tahun 2018.

Direktorat Jenderal Pajak RI. (2018). Laporan Kinerja Tahun 2017.

Direktorat Jenderal Pajak RI. (2017). Laporan Kinerja Tahun 2016.

Ispriyarso, B. (2014). Analisis Yuridis Terhadap Kedudukan Pengadilan Pajak Sebagai Pengadilan Khusus Di Lingkungan Peradilan Tata Usaha Negara. Masalah-Masalah Hukum, 43(1), 40-48. https://doi.org/10.14710/mmh.43.1.2014.40-48

Jan, T. S. (2012). Analisis Kebijakan Dualisme Pembinaan Pengadilan Pajak terhadap Kebebasan Hakim dalam Memeriksa dan Memutus Sengketa Pajak. Universitas Indonesia.

Ketua Mahkamah Agung Republik Indonesia. (2020). Keputusan Ketua Mahkamah Agung Republik Indonesia Nomor 96/KMA/SK/IV/2020 tentang Peraturan Tata Tertib Pemilihan Ketua Mahkamah Agung Republik Indonesia.

Ketua Pengadilan Pajak. (2021). Keputusan Ketua Pengadilan Pajak Nomor KEP-01/PP/2021 tentang Tata Tertib Pemilihan Ketua Pengadilan Pajak.

Kornhauser, L. A. (2012). Is Judicial Independence a Useful Concept? In S. B. Burbank \& B. Friedman (Ed.), Judicial Independence at the Crossroads: An Interdisciplinary Approach (hal. 45-55). SAGE Publications, Inc. https://doi.org/10.4135/9781452229577.n3

Kurniawan, B. H. (2020). Tinjauan Terhadap Pengaruh Dualisme Pembinaan Pengadilan Pajak Terhadap Independensi Hakim. PKN STAN.

Mahkamah Agung RI, Komisi Yudisial RI. (2009). Keputusan Bersama Ketua Mahkamah Agung RI dan Ketua Komisi Yudisial RI Nomor 047/KMA/SKB/IV/2009 dan 02/SKB/P.KY/IV/2009 tentang Kode Etik dan Pedoman Perilaku Hakim.

Mahkamah Agung Republik Indonesia. (2010). Cetak Biru Pembaruan Peradilan 2010 - 2035.

Mahkamah Agung Republik Indonesia. (2015). Peraturan Mahkamah Agung Nomor 7 Tahun 2015 tentang Organisasi dan Tata Kerja Kepaniteraan dan Kesekretariatan Pengadilan.

Mahkamah Agung Republik Indonesia. (2019). Laporan Tahunan 2018 
Mahkamah Konstitusi Republik Indonesia. (2020). Putusan Nomor 10/PUU-XVIII/2020.

Pudyatmoko, Y. S. (2009). Pengantar Hukum Pajak. Penerbit Andi.

Putri, N. C. (2019). Persepsi Terhadap Independensi Kekuasaan Kehakiman Dalam Penyelesaian Sengketa Pajak Di Pengadilan Pajak [Universitas Brawijaya]. http://repository.ub.ac.id/id/eprint/177232

Rahmatullah, I. (2013). Rejuvinasi Sistem Checks and Balances Dalam Sistem Ketatanegaraan di Indonesia. JURNAL CITA HUKUM, 1(2), 215-226. https://doi.org/10.15408/jch.v1i2.2992

Republik Indonesia. (1986). Undang-Undang Nomor 2 Tahun 1986 tentang Peradilan Umum.

Republik Indonesia. (1986). Undang-Undang Nomor 5 Tahun 1986 tentang Peradilan Tata Usaha Negara.

Republik Indonesia. (2002). Undang-Undang Nomor 14 Tahun 2002 tentang Pengadilan Pajak.

Republik Indonesia. (2004). Undang-Undang Nomor 4 Tahun 2004 tentang Kekuasaan Kehakiman.

Republik Indonesia. (2004). Undang-Undang Nomor 8 Tahun 2004 tentang Perubahan atas UndangUndang Nomor 2 Tahun 1986 tentang Peradilan Umum.

Republik Indonesia. (2004). Undang-Undang Nomor 9 Tahun 2004 tentang Perubahan Atas UndangUndang Nomor 5 Tahun 1986 tentang Peradilan Tata Usaha Negara.

Republik Indonesia. (2009). Undang-Undang Nomor 48 Tahun 2009 tentang Kekuasaan Kehakiman.

Republik Indonesia. (2009). Undang-Undang Nomor 49 Tahun 2009 tentang Perubahan Kedua atas Undang-Undang Nomor 2 Tahun 1986 tentang Peradilan Umum.

Republik Indonesia. (2009). Undang-Undang Nomor 51 Tahun 2009 tentang Perubahan Kedua Atas Undang-Undang Nomor 5 Tahun 2012 Tentang Peradilan Tata Usaha Negara.

Rumadan, I. (2012). Eksistensi Pengadilan Pajak Dalam Sistem Peradilan Di Indonesia. Jurnal Hukum dan Peradilan, 1(1), 35.

https://doi.org/10.25216/JHP.1.1.2012.35-62

Sekretariat Pengadilan Pajak. (n.d.). Statistik. Diakses tanggal 25 Oktober 2021, dari http://setpp.kemenkeu.go.id/statistik.

Siallagan, H. (2016). Penerapan Prinsip Negara Hukum Di Indonesia. Sosiohumaniora, 18(2), 131-137. https://doi.org/10.24198/sosiohumaniora.v18i2.9 947

Simamora, J. (2014). Tafsir Makna Negara Hukum Dalam Perspektif Undang-Undang Dasar Negara Republik Indonesia Tahun 1945. Jurnal Dinamika Hukum, 14(3). https://doi.org/10.20884/1.jdh.2014.14.3.318

Subiyanto, A. (2012). Mendesain Kewenangan Kekuasaan Kehakiman Setelah Perubahan UUD 1945. Jurnal Konstitusi, 9(4), 661-680.

https://jurnalkonstitusi.mkri.id/index.php/jk/artic le/view/149

Sulistiyono, A. (2018). Sistem Peradilan Di Indonesia
Wijayanti, N. (2018). Independensi Hakim Pengadilan Pajak dalam Penyelesaian Sengketa Perpajakan di Indonesia. Universitas Islam Indonesia. 